\title{
Pendekatan Holistik Integratif Berbasis Penguatan Keluarga pada Pendidikan Anak Usia Dini Full Day
}

\author{
Maulidya Ulfah ${ }^{1}$ \\ Pendidikan Islam Anak Usia Dini, Institut Agama Islam Negeri Syekh Nurjati Cirebon \\ DOI: $\underline{10.31004 / o b s e s i . v 4 i 1.255}$
}

\begin{abstract}
Abstrak
Holistik integratif merupakan pendekatan yang memerlukan kesinambungan dan keselarasan layanan bagi anak usia dini. Kerjasama antar bebagai pihak sangat diperlukan untuk keberhasilan pendekatan holistik integratif dalam lembaga Pendidikan Anak Usia Dini (PAUD). Oleh karena itu, penelitian ini dilakukan bertujuan untuk mengetahui gambaran pendekatan holistik dan integratif berbasis penguatan keluarga dan hasil penerapannya pada PAUD Full Day di Kota Yogyakarta. Metode penelitian yang digunakan ialah deksriptif kualitatif dengan menggunakan teknik pengumpulan data melalui wawancara mendalam, dokumentasi dan observasi secara terstuktur. Hasil penelitian yang dilakukan yakni ditemukan perencanaan, pelaksanaan dan evaluasi pendekatan holistik integratif berbasis penguatan keluarga di KB TK 'Aisyiyah Ahmad Dahlan Full Day Kota Yogyakarta dengan hasil yang sesuai standar dari Peraturan Presiden No 60 tahun 2013. Hal ini terlihat dari hasil pengumpulan data yang dilakukan meliputi lima layanan/program pelaksanaan yaitu pendidikan, pengasuhan, gizi, kesehatan dan perlindungan. Dukungan keluarga sebagai penyelenggaran pendidikan anak di rumah dan partisipasi aktif dalam kegiatan di sekolah menjadi faktor pendukung keberhasilan pendekatan holistik integratif pada PAUD full day.
\end{abstract}

Kata kunci : holistik integratif; anak usia dini; keluarga; paud

\begin{abstract}
Holistic integrative approach it requires continuity and alignment services for early childhood, not only in the field of education, but also covers nutrition, health care, nurturing and protection. Who are responsible for the education of children at home have an important role in organizing holistic integrative. This research to know the description of holistic and integrative approach to strengthening family-based and the results of its application on early childhood development in the city of Yogyakarta. The research method used is qualitative deksriptif. The results of the research can be planning, implementation and evaluation of integrative holistic approach in KB TK 'Aisyiyah Ahmad Dahlan Yogyakarta is very good. This is apparent from the results of the data collection carried out includes five service/program implementation, namely education, parenting, nutrition, health and protection. Support families as the education at home and active participation in the activities at the school become a supporting factor for the success of integrative holistic approach on early childhood education and full day.
\end{abstract}

Keywords: holistic integrative; early childhood; family

Copyright (c) 2019 Maulidya Ulfah1

$\triangle$ Corresponding author:

Email Address : ulfah@syekhnurjati.ac.id (Cirebon_Jawa Barat)

Received 31 July 2019, Accepted 9 September 2019, Published 12 September 2019

10 | Jurnal Obsesi : Jurnal Pendidikan Anak Usia Dini, 4(1), 2020 


\section{PENDAHULUAN}

Penyelenggaraan Pendidikan Anak Usia Dini (PAUD) sebagai bentuk pendidikan informal yaitu berupa pendidikan keluarga menjadi bagian penting di masyarakat untuk mewujudkan tujuan pendidikan nasional yang sudah tercantum dalam Undang-Undang Sistem Pendidikan Nasional N0. 20 Tahun 2003 pasal 3 dan pasal 28 ayat 5. Pelaksanaan pembelajaran dalam lingkup anak usia dini, sebagaimana dalam Peraturan Menteri Pendidikan dan Kebudayaan No 137 tahun 2014 memiliki peranan penting dalam membentuk kepribadian anak sehingga setiap proses pembelajaran seharusnya juga mempertimbangkan perlunya mengevaluasi setiap nilai-nilai pendidikan dalam kegiatan pembelajaran yang mampu menstimulasi perkembangan anak yaitu kognitif, bahasa, fisik motorik, sosial, emosi, seni dan kreativitas sehingga mampu menghasilkan lulusan yang berkualitas dan dapat menerapkannya dalam kehidupan sehari-hari.

Keluarga memiliki peranan penting dalam mewujudkan pendidikan yang holistik dan integratif. Hasil penelitian di berbagai negara menunjukkan bahwa kesinambungan dan keselarasan layanan PAUD pada lembaga dengan pengasuhan di keluarga menunjukkan dampak positif pada keberhasilan anak di sekolah dalam jangka waktu yang panjang. Oleh karena itu, program penyelenggaraan PAUD berbasis keluarga akan menguatkan peran keluarga dan peran lembaga dalam menyediakan layanan pendidikan anak usia dini yang komprehensif dan terintegrasi. (Suyadi, 2013)

Berdasar hasil observasi di satuan PAUD di Yogyakarta banyak ditemukan satuan PAUD yang mengajarkan pembelajaran di sekolah namun tidak diterapkan kembali di rumah (Juli 2019).

Layanan stimulasi holistik integratif terdiri dari layanan pendidikan, kesehatan, gizi, perawatan, pengasuhan, perlindungan dan kesejahteraan. (Kemendikbud, 2015) Pada pengembangan pelaksanaannya, satuan PAUD harus melibatkan pihak terkait seperti instansi pemerintah, organisasi kemasyarakatan, organisasi profesi, tokoh masyarakat, dan orang tua (KEMENDIKBUD, 2015e). Tujuan dari pendekatan holistik integratif pada PAUD yang tercantum dalam Peraturan Presiden (PERPRES) No 60 Tahun 2013. Prinsip-prinsip yang dikembangkan dalam pendidikan anak usia dini holistik dan integratif yakni bersifat menyeluruh dan terintegrasi, berkesinambungan dan konsisten, tidak ada diskriminasi dalam memberikan pelayanan, pelayanan yang tersedia mudah terjangkau dan dapat diterima masyarakat, peran dari masyarakat, berdasarkan budaya yang bersifat konstruktif, dan good governance.

Dalam website Kemendikbud, jumlah data satuan PAUD 231.634 namun realita di lapangan tetapi tidak diikuti dengan semangat dan keterampilan dalam mendidik anak usia dini yang terintegrasi secara meyeluruh pada kehidupan anak di rumah. Hal ini memunculkan kesan bahwa pendidikan anak usia dini "hanya" menjadi tanggung jawab satuan PAUD tersebut. Regio Emilia sebagai salah satu tokoh dalam bidang pendidikan anak usia dini menyebutkan bahwa guru dalam pendidikan anak usia dini itu ada tiga yakni orang tua atau keluarga, pendidik atau pengasuh dan lingkungan. (Suyadi, 2013) Artinya pendidikan tidak diserahkan hanya pada sekolah akan tetapi juga keluarga dan masyarakat.

Keterlibatan orang tua menjadi hal yang utama dalam pendidikan anak usia dini demi mewujudkan anak yang cerdas, tangguh dan mandiri. Keluarga adalah kelompok kecil dalam masyarakat, masing-masing anggota keluarga memiliki hak dan kewajiban. Keluarga adalah tempat pertama bagi anak-anak belajar, dalam keluarga anak belajar tentang keyakinan, sifat-sifat mulia, komunikasi, interaksi sosial serta ktrampilan dalam hidup (Helmawati, 2014).

Hal ini selaras dengan perintah dalam Al Qur'an, bahwa orang tua mendapat amanah mampu membentuk akhlaqul karimah terhadap anak-anaknya. Ayat Al-Qur'an yang berkaitan dengan itu adalahartinya: "Dan (ingatlah) ketika Luqman berkata kepada anaknya, di waktu ia memberi pelajaran kepadanya: "Hai anakku, janganlah kamu mempersekutukan Allah, 
sesungguhnya mempersekutukan (Allah) adalah benar-benar kezaliman yang besar". (Q.S Luqman: 13).

Keselarasan pendidikan yang dilaksanakan di satuan PAUD dan di rumah diakui oleh para ahli pendidikan sebagai salah satu faktor penentu keberhasilan pendidikan anak secara menyeluruh. Oleh karena itu, satuan PAUD penting untuk dapat memfasilitasi penyelenggaraan program PAUD holistik integratif berbasis keluarga sebagai upaya keselarasan dan keberlanjutan antara pendidikan yang dilakukan di lembaga dan pendidikan yang dilakukan di rumah.

Munculnya model-model pendidikan baru dimotivasi oleh tujuan pendidikan masa kini yang lebih kompleks. Diantara model pendidikan baru tersebut muncul sekolah sehari atau full day school yang kebanyakan menyandang predikat Islam. Model pendidikan fullday school pada masa sekarang semakin digemari masyarakat sebagai alternatif pendidikan unggulan, berusaha menempatkan aspek kualitas di atas segala-galanya. Konsep ini mengadopsi joy full learning yang diterapkan di Jepang dimana anak belajar satu hari penuh selama lima atau enam hari di sekolah. (Jamal, 2017).

Clark dan Kirk (2000) melihat dari segi sosial, menemukan bahwa anak-anak yang bersekolaj seharian lebih mudah bergabung dan bersosialisasi dengan teman sebayanya dan memiliki ketrampilan sosial (social skills) yang lebih baik. Para ahli mengungkapkan bahwa anak yang bersekolah di full day lebih mandiri, mengalami kecemasan yang rendah, lebih berani untuk mendekati (berbicara) dengan guru, lebih jarang tidak masuk sekolah dan lebih survive dalam menghadapi tantangan dimasa yang akan datang. Clark dan Kirk (2000) menambahkan bahwa anak-anak yang bersekolah di fullday secara perilaku dan motivasi mereka lebih positif dan produktif.

Melihat fenomena yang ditemukan, penulis tertarik untuk melakukan penelitian tentang pengembangan pendekatan holistik integratif berbasis penguatan keluarga pada satuan PAUD full day yang ada di Kota Yogyakarta. Satuan PAUD merupakan lembaga penyelenggaraan pendidikan tingkat usia dini yang menyelenggarakan proses pendidikan dari anak usia dua tahun sampai enam tahun. Penelitian ini menggambarkan tentang perencanaan, pelaksanaaan dan hasil penerapan PAUD holistik dan integratif berbasis penguatan keluarga pada PAUD Full Day di Kota Yogyakarta. Penelitian ini bertujuan untuk mengetahui pendekatan holistik dan integratif berbasis penguatan keluarga dan hasil penerapannya. Adapun harapan manfaat secara teoritis dan praktis dari penelitian ini yakni dapat dijadikan bahan masukan untuk menerapkan model holistik integratif pada satuan PAUD dan dapat dijadikan bahan masukan untuk memotivasi satuan PAUD dalam menerapkan model holistik integratif.

Metode yang digunakan dalam penelitian ini adalah deskriptif kualitatif, yang berupa kata-kata tertulis atau lisan tentang orang-orang dan perilaku yang dapat diamati (Moleong, 2005) dari kepala sekolah, guru, yayasan dan orang tua di KB TK 'Aisyiyah Nyai Ahmad Dahlan Yogyakarta. Penelitian ini memberikan gambaran atau uraian atas sesuatu keadaan (Rony Kountur, 2005: 105) yang merupakan perencanaan, pelaksanaan dan hasil pendekatan holistik integratif pada PAUD full day.

Tahapan penelitian yang dilakukan mengacu pada pendapat Dr. Endang S. Sedyaningsih Mahamit (2006) dalam Asep Suryana (2007:5) yakni menentukan permasalahan, melakukan studi literatur dari referensi tentang holistik integratif pada PAUD, menetapkan lokasi penelitian, studi pendahuluan, penetapan teknik pengumpulan data (wawancara, dokumentasi, observasi), analisis data dan validasi data. Penelitian ini diharapkan dapat memecahkan rumuan masalah yaitu pelaksanaan dan hasil pendekatan holistik integratif berbasis penguatan keluarga.

Adapun sumber data dalam penelitian ini adalah kepala sekolah yang diwawancarai, siswa yang dioservasi, guru-guru yang diwawancarai dan diobservasi, orang tua, yayasan dan karyawan yang penulis tentukan sendiri berdasarkan pertimbangan dari kepala sekolah, dokumen-dokumen, dan arsip-arsip di sekolah yang mendukung sumber data utama. 
DOI: $\underline{10.31004 / o b s e s i . v 4 i 1.255}$

Metode pengumpulan data yang digunakan yakni melalui observasi, wawancara atau interview dan dokumentasi. Data yang diperoleh melalui hasil wawancara maupun observasi dipadukan dengan data yang diperoleh dari teknik pengumpulan data yang ketiga, yaitu dokumentasi. Teknik ini bertujuan untuk mendapatkan data yang akurat, serta dapat dipertanggungjawabkan keabsahannya.

Analisis data dilakukan sejak awal penelitian dimulai hingga penyusunan hasil akhir penelitian. Konsep analisa yang dipergunakan adalah konsep analisa data mengalir (flow model analysis), yakni konsep analisa yang meliputi langkah-langkah berikut; reduksi data, display data, pengambilan kesimpulan dan verifikasi (Milles \& Huberman, 1992).

Penulis melakukan pemeriksaan keabsahan data yang didasarkan pada kriteria derajat kepercayaan (credibility). Berdasarkan kriteria ini, maka teknik yang digunakan adalah triangulasi, yaitu teknik pemeriksaan keabsahan data yang memanfaatkan sesuatu yang lain di luar data itu untuk keperluan pengecekan atau sebagai pembanding terhadap data itu (Moleong, 2005). Pada penelitian ini, triangulasi yang digunakan penulis adalah: pertama, triangulasi sumber dengan membandingkan informasi yang dikatakan subyek dalam penelitian ini, kedua, triangulasi metode dengan menggunakan berbagai metode pengumpulan data untuk menggali data yang sejenis.

\section{HASIL DAN PEMBAHASAN}

\section{Gambaran Umum KB TK 'Aisyiyah Ahmad Dahlan Full Day}

Pada tahun 1999 Pimpinan Aisyiyah Cabang Kotagede mendirikan Taman KanakKanak Aisyiyah Nyai Ahmad Dahlan Islam Terpadu. Lokasi Sekolah merupakan Waqaf dari Bapak/Ibu Zubaidi, dengan luas tanah dan bangunan $1.113 \mathrm{~m}^{2}$. Sekolah ini beralamat di Pilahan RT 44 RW 13, Kelurahan Rejowinangun, Kecamatan Kotagede, Kota Yogyakarta, Provinsi Daerah Istimewa Yogyakarta. TK 'Aisyiyah Nyai Ahmad Dahlan Full Day telah terakredetasi A dengan nomor SK akredetasi No.PAUD-TK/3471/0013/06/2017 sejak tanggal 14 juni 2017.

KB TK ‘Aisyiyah Nyai Ahmad Dahlan Full Day memiliki visi terwujudnya anak didik yang unggul dalam kecerdasan spiritual, emosional dan intelektual. Adapun misinya meliputi membiasakan beribadah yang baik, melatih hafalan juz amma, hadits, dan doa-doa sehari-hari dengan lafal yang benar, mengenalkan kisah Nabi dan para sahabat masa Rasulullah SAW, meningkatkan kemampuan baca tulis Al-Qur'an. membekali anak dengan keteladanan, mengembangkan kemampuan berkomunikasi dan bersosialisasi, membiasakan hidup mandiri. mengenalkan angka dan huruf, mengembangkan ketrampilan, kreatifitas dan potensi yang dimiliki anak, dan mengembangkan minat anak dalam melakukan percobaan sederhana untuk menghasilkan sesuatu yang baru.

KB TK 'Aisyiyah Nyai Ahmad Dahlan Full Day secara keseluruhan memiliki 35 orang pendidik dan tenaga kependidikan. Jumlah murid yang mencapai 200 anak pada tahun pelajaran 2018/2019

Kurikulum di KBTK 'Aisyiyah Nyai Ahmad Dahlan Full Day mengacu pada Peraturan Menteri Pendidikan dan Kebudayan No. 146 tahun 2014 yaitu Kurikulum 2013 dan kurikulum dari Yayasan 'Aisyiyah. Satuan PAUD ini melaksanakan empat jenis program yaitu program reguler, program ekstrakurikuler, program kokurikuler, dan program full day. Pelaksanaan Program ekstrakurikuler dan kokurikuler diampu oleh pendamping/guru yang sesuai dengan bidangnya masing-masing.

Program reguler adalah program kegiatan yang menggunakan alokasi waktu yang telah ditentukan yaitu dimulai dari jam 07.00 - 11.00 WIB. Program regular ini menggunakan pendekatan area yang berjumlah 10 area dengan tiap hari melakukan lima area. Program ekstrakurikuler merupakan kegiatan yang dilakukan dengan tujuan untuk mengembangkan minat dan bakat anak. Terdapat beberapa macam ektrakurikuler yaitu computer kids, drumband, bermain angklung, melukis, menyanyi dan menari. 
Program kokurikuler bertujuan untuk lebih mendalami pembelajaran bagi semua anak. Adapun kokurikuler ini ada dua kegiatan yaitu renang dan tahfidz (menghafal suratsurat pendek dan ayat-ayat pilihan). Pelaksanaan program full day ini dimulai setelah program reguler sampai pukul $14.30 \mathrm{WIB}$ dan ada program yang sampai jam $16.30 \mathrm{WIB}$. Kurikulum yang digunakan untuk program full day yakni kurikulum keagamaan yang meliputi tahfidz (hafalan surat-surat pendek), hafalan doa sehari-hari dan hadits, aqidah uluhiyah (mengenal allah dalam segala bentuk ibadah), aqidah rububiyah (mengenal allah dalam hal penciptaan dan mengatur segala sesuatu), shiroh (cerita nabi dan sahabat sahabat nabi ) dan bahasa arab, dilanjutkan dengan makan siang, sholat dzhuhur berjamaah, evaluasi dan tidur siang.

Dukungan orang tua dan masyarakat dalam pengembangan satuan PAUD dari Yayasan 'Aisyiyah dan komite sekolah dalam baik moril maupun material terlihat dari bangunan satuan PAUD yang kuat, sarana dan prasarana yang lengkap baik di dalam kelas maupun luar kelas serta prestasi sekolah, guru dan anak serta minat orang tua yang tinggi untuk menyekolahkan anak-anaknya di lingkungan satuan PAUD sehingga memenuhi kriteria yang sudah distandarkan oleh Peraturan Menteri Pendiidkan dan Kebudayaan No 137 tahun 2014.

\section{Perencanaan PAUD Holistik Integratif Berbasis Penguatan Keluarga di TK 'Aisyiyah Ahmad Dahlan Full Day.}

Sebagai salah satu bentuk komitmen dalam mejamin hak tumbuh kembang anak usia dini dan terjaminnya akses terhadap pendidikan pra-sekolah dasar yang berkualitas, Pemerintah mengeluarkan Peraturan Presiden Nomor 60 Tahun 2013 tentang PAUD HI (holistik integratif). Dalam aturan tersebut memuat tujuan dan prinsip penyelenggaraan sehingga pendekatan holistik dan integratif di satuan PAUD dapat terlaksana dengan baik. (KEMENDIKBUD, 2015).

Beberapa pihak yang terkait pada penyelenggaraan PAUD holistik integratif diantaranya kerjasama dengan dinas pendidikan Kota Yogyakarta, dinas kesehatan Kota Yogyakarta, RSIA PKU Kecamatan Kotagede, polsek, organisasi mitra Ikatan Guru Taman Kanak-kanak (IGTK), Ikatan Guru Burstanul Athfal (IGB), Kelompok Kerja Guru (KKG), tokoh masyarakat, orang tua, beberapa tempat yang dimanfaatkan untuk fieldtrip atau wisata edukasi di luar sekolah.

Pendekatan holistik integratif yang diterapkan di KB TK 'Aisyiyah Nyai Ahmad Dahlan Full Day merupakan pembelajaran terpadu di lingkungan sekolah, baik itu dalam kegiatan formal maupun non formal dengan mengacu kepada perpaduan kurikulum Nasional Peraturan Menteri Pendiidkan dan Kebudayaan No. 146 tahun 2014 dan kurikulum yayasan atau sekolah.

Perencanaan pendekatan holistik integratif berbasis keluarga di TK Aisyiyah Nyai Ahmad Dahlan Full Day dimulai dengan adanya rapat lembaga antara Sekolah dengan Yayasan yang menghasilkan program kerja lima tahun, program kerja tahunan TK Aisyiyah Nyai Ahmad Dahlan Full Day yang terdiri dari lima program yakni program kesehatan, gizi, rangsangan pendidikan, pengasuhan dan perlindungan.

Beberapa perencanaan kegiatan dari layanan kesehatan berupa jadwal kunjungan pemeriksaan deteksi dini tumbuh kembang anak dari PKU Muhammadiyah, jadwal pemeriksaan dari puskesmas, dan jadwal pemeriksaan rutin yang dilakukan oleh guru kelas. Perencanaan pada layanan kesehatan juga dilakukan melalui pengadaan UKS dan perlengkapannya sehingga dapat digunakan oleh anak dengan sebaik-baiknya. Perencanaan pada layanan gizi yaitu melalui pembuatan jadwal harian pemberian snack dan makanan tambahan. Adapun dalam layanan rangsangan pendidikan, perencanaan kegiatan melalui Program tahunan, program semester, Rencana Pelaksanaan Pembelajaran Mingguan (RPPM) dan Rencana Pelaksanaan Pembelajaran Harian (RPPH) yang dilaksanakan melalui kegiatan di dalam kelas yang meliputi enam bidang pengembangan anak usia dini (kognitif, bahasa, 
DOI: $\underline{10.31004 / o b s e s i . v 4 i 1.255}$

fisik motorik, sosial, emosi, seni kreativitas, nilai agama dan moral serta kegiatan-kegiatan lain yang dilaksanakan di luar kelas dan di luar lingkungan PAUD. Perencaann layanan pengasuhan holistk integratif meliputi jadwal kegiatan parenting setiap bulan dan toilet training yang dilaksanakan setiap hari di sekolah. Layanan perlindungan dilakukan dengan melalui kegiatan piket guru dan penjaga sekolah serta perencanaan pengadaan sarana prasarana yang mengacu pada UU Perlindungan anak.

Perencanaan pendekatan holistik integratif di dilaksanakan dengan melibatkan semua pihak, baik Yayasan maupun keluarga, yang tergabung dalam Komite Sekolah. Perencanaan kegiatan holistik integratif ini disampaikan kepada semua orang tua pada saat pertemuan rutin awal semester. Hal ini menjadikan perencanaan yang telah ditetapkan dapat selaras dan berkesinambungan dengan pendidikan di dalam keluarga.

\section{Pelaksanaan Pendekatan Holistik Integratif Berbasis Penguatan Keluarga di KB TK 'Aisyiyah Ahmad Dahlan Full Day.}

Mekanisme operasional pelaksanaan PAUD holistik integratif yang diselenggarakan secara integrasi, artinya pendidikan yang diselenggarakan akan mendukung keberadaan posyandu dan akan memperkuat layanan BKB (Bina Keluarga Berencana) (Alimoeso, 2013).

Adapun pelaksanaan PAUD holistik integratif berbasis penguatan keluarga di KB TK 'Aisyiyah Ahmad Dahlan Full Day terbagi dalam lima layanan dan diselenggarakan secara terintegrasi menyeluruh dan telah tercantum dalam perencanaan program kerja sekolah.

Lima layanan tersebut pertama, layanan kesehatan; hasil observasi yang dilakukan pada program kesehatan menunjukkan setiap awal tahun pelajaran baru, sekolah memiliki data anak yang diisi oleh orang tua saat pendaftaran. Data tersebut berfungsi sebagai bentuk perlindungan dan deteksi dini tumbuh kembang dan pengenalan tingkat kesehatan anak. Sekolah juga memiliki Kartu Menuju Sehat (KMS) Anak Sekolah TK-SD yang diberikan kepada setiap orang tua untuk mengetahui pertumbuhan dan perkembangan anak selama di sekolah.

Pelaksanaan program kesehatan dilakukan melalui pengadaan buku deteksi tumbuh kembang anak. Buku ini berisi laporan hasil pemeriksaan anak yang meliputi berat badan, tinggi badan, status gizi, kebersihan diri, kebersihan gigi dan mulut dan kesehatan umum. Buku ini diisi saat kegiatan pemeriksaan rutin oleh guru seperti kegiatan gosok gigi, mencuci tangan, membuang sampah pada tempatnya, dan lain-lain. Setiap kelas memiliki buku deteksi tumbuh kembang anak masing-masing sehingga guru lebih mudah mengetahui pertumbuhan dan perkembangan anak. Peran keluarga dalam kesehatan yaitu dukungan orang tua untuk menjaga kebiasaan di sekolah juga dilaksanakan di rumah.

Pengadaan poliklinik atau UKS menjadi salah satu sarana prasarana pendukung pelaksanaan dari layanan kesehatan. Salah satu fasilitasnya ialah memiliki buku rekam medik dana sehat muhammadiyah. Buku ini memuat data anak yang menjadi pasien poliklinik berupa identitas, tanggal dan jam, anamnesis pemeriksaan, diagnosis terapi, ICD dan dokter yang menangani. Poliklinik atau UKS KB TK 'Aisyiyah Ahmad Dahlan Full Day menjadi juara 1 lomba UKS Tingkat Kota Yogyakarta pada tahun 2018.

Kedua, layanan gizi ; layanan gizi dilaksanakan melalui pemberian makanan tambahan yang diberikan setiap hari dengan menu pokok makan siang dan snack yang bervariasi, minum susu bersama yang dibawa sesuai keinginan anak dan sosialisasi gizi seimbang pada saat kegiatan belajar mengajar di kelas. Peran keluarga dalam program gizi selain memenuhi kebutuhan gizi seimbang anak di rumah, juga melalui kebiasaan membawa bekal snack non MSG untuk dibawa anak ke sekolah, menanamkan kebiasaan baik untuk mengkonsumsi makanan bergizi sehingga asupan nutrisi anak selalu terpenuhi.

Kegiatan ini dilakukan untuk menjaga agar anak tetap tumbuh dan berkembang secara optimal, memenuhi kebutuhan energinya selama di sekolah. Beberapa tujuan keterampilan yang dimiliki anak dari kegiatan ini diantaranya anak terbiasa makan sendiri, 
makan makanan yang bervariasi, tidak jajan sembarangan, minum susu, memahami manfaat sayuran buah-buahan, dan minuman.

Ketiga, layanan rangsangan pendidikan; program rangsangan pendidikan direncanakan sesuai tahap perkembangan anak dan diberikan saat kegiatan pembelajaran di kelas melalui pendekatan area-area pembelajaran, media dan sumber belajar untuk menstimulasi enam aspek perkembangan anak sesuia dengan Peraturan Menteri Pendiidkan dan Kebudayaan No. 137 tahun 2014.

Hasil observasi pada program rangsangan pendidikan di kelas menunjukkan stimulus yang diberikan guru sangat nyata. Hal tersebut terlihat dari kegiatan-kegiatan yang dilakukan setiap hari di area-area pembelajaran yang telah ada. Area-area pembelajaran tersebut meliputi area matematika, area bahasa, area luar kelas, area agama, area seni, area drama, area IPA, area pasir air, area baca tulis dan area balok.

Kegiatan yang dilakukan anak di area-area yang ada, telah direncanakan dan disesuaikan dengan usia anak serta tahap perkembangannya. Pembelajaran di area-area dilakukan secara tematik. Hal ini sesuai dengan ketentuan bahwa tema pembelajaran yang dipilih harus memperhatikan beberapa hal yakni tema yang dekat dengan kehidupan anak, sederhana, serta tema tersebut bisa berupa kejadain yang dialami secara spontan (KEMENDIKBUD, 2015).

Beberapa contoh kegiatan dalam layanan pendidikan seperti bercerita, bermain alat musik, berdoa, dan bermain sesuai area. Selain itu stimulus yang diberikan oleh pendidik juga dilakukan melalui media dan sumber belajar. Media dan sumber belajar yang digunakan selain bertujuan untuk menstimulasi perkembangan anak juga untuk membuat anak merasa nyaman dan senang.

Stimulasi yang diberikan di sekolah sebagai bentuk pelaksanaan program rangsangan pendidikan digunakan pendekatan saintifik yakni dilakukan secara bertahap, melalui berbagai cara, belajar melalui sosialisasi, bertujuan untuk mengembangkan karakter, mengembangkan kecakapan hidup dan melalui pengadaan lingkungan yang kondusif (KEMENDIKBUD, 2015).

Program rangsangan pendidikan tidak hanya dilakukan di dalam kelas, tetapi juga di luar kelas misalnya saat puncak tema pembelajaran yang bertujuan untuk mengenalkan lingkungan sekitar pada anak. Sekolah juga mengadakan ekstrakurikuler untuk mengembangkan minat dan bakat anak yang dilaksanakan di luar jam pelajaran.

Peran keluarga pada program rangsangan pendidikan dilakukan melalui kegiatan bermain bersama. Orang tua terlebih dahulu perlu memahami mengenai tahap perkembangan anak usia dini, sehingga pemberian stimulasi yang diperoleh anak di rumah selaras dengan stimulasi yang anak dapatkan di sekolah. Upaya yang dilakukan sekolah yakni dengan memberikan setiap hari selebaran laporan kegiatan harian anak berikut capaian-capian perkembangan sehingga orang tua dapat memantau kegiatan anak seharihari.

Keempat, layanan pengasuhan; bentuk pelaksanaan program pengasuhan diantaranya melalui kegiatan parenting yang dilakukan pada minggu ketiga setiap bulannya dan toilet training. Kegiatan parenting tersebut meliputi pola pengasuhan, permasalahan anak, peningkatan bakat minat dan pembelajaran IT untuk anak usia dini. Peran keluarga pada pelaksanaan program ini sangat diperlukan untuk mengimplementasikan apa yang menjadi kebiasaan baik di sekolah untuk diterapkan di rumah. Layanan pengasuhan toilet training misalnya menyiram air setelah buang air kecil sebanyak tujuh gayung, cuci tangan sesudah buang air kecil atau buang air besar menggunakan sabun. Pelaksanaan program parenting bagi orang tua biasanya dilakukan melalui kegiatan pengajian, diskusi mengenai nilai-nilai pendidikan anak dalam islam, dan sharing permasalahan anak dengan narasumber psikolog atau tokoh masyarakat. 


\section{DOI: $10.31004 /$ obsesi.v4i1.255}

Kelima, layanan perlindungan; pelaksanaan program perlindungan dimulai sejak orang tua mendaftarkan anak di sekolah. Orang tua diwajibkan untuk memberikan salinan kartu keluarga/ akta kelahiran dan KTP anak, mengisi data anak yang meliputi keterangan pribadi, keterangan tempat tinggal, keterangan kesehatan, kegemaran, keterangan orang tua kandung atau wali, keterangan jasmani dan kesehatan anak sebelum masuk sekolah, pendidikan agama dan harapan orang tua selama anak di sekolah. Data-data tersebut menjadi salah satu bentuk bukti legalitas perlindungan anak yang dilaksnakan satuan PAUD.

Lingkungan belajar di dalam ataupun di luar satuan PAUD diciptakan untuk mendorong anak bereksplorasi, bereskperimen, bermain secara bermakna dan menantang kemampuan berpikir anak serta membuatnya merasa nyaman dan senang. Hal ini sesuai dengan kebijakan bahwa penataan lingkungan belajar yang baik disesuaikan dengan model pembelajaran yang digunakan dan harus menjamin keamanan dan kenyamanan anak (KEMENDIKBUD, 2015).

Perlindungan dilakukan juga pada saat pengantaran anak diwaktu datang dan penjemputan anak saat pulang yang disesuaikan dengan SOP yang berlaku di sekolah dan di lakukan oleh guru piket. Keamanan mainan menjadi salah satu bagian layanan perlindungan dimana mainan yang aman dan nyaman akan lebih mendukung pertumbuhan dan perkembangan anak secara optimal. Selain itu, karena sekolah ini memiliki dua lantai maka keamanan tangga dan pagar menjadi kunci penting keamanan anak.

\section{Evaluasi PAUD Holistik Integratif Berbasis Penguatan Keluarga di TK TK ‘Aisyiyah Ahmad Dahlan Full Day}

Pengembangan holistik integratif diterapkan melalui praktik pembelajaran yang diterapkan untuk mengembangkan enam aspek perkembangan. Program pengembangan pembelajaran dirancang sesuai dengan minat, kekuatan dan kebutuhan anak. Adapun penilaian yang dilakukan meliputi enam aspek perkembangan anak yang mengarah pada tercapainya kompetensi inti yang menjadi standar tingkat pencapaian perkembangan anak. Hal tersebut sesuai dengan prinsip-prinsip penilaian pada anak usia dini yakni mendidik, berkesinambungan, objektif, akuntabel, transparan, sistematis, menyeluruh, bermakna (KEMENDIKBUD, 2015).

Penilaian dilakukan di lingkungan sekolah yang mengandung muatan prinsip, cara, pendekatan dan orientasi dapat dipandang efektif, baik dilihat dari penilaian pihak atasan, reputasi sekolah, cakupan tiga ranah psikologis pembelajaran, kegembiraan santri, keaktivan dan rasa senang anak dalam mengikuti pembelajaran di sekolah.

Selanjutnya dari pendapat orang tua yang menyatakan, bahwa anaknya selalu aktif dan gembira mengikuti pembelajaran di sekolahnya. Ukuran keberhasilan memang sulit, namun hal ini dapat diketahui dari ekspresi perilaku anak dan kebiasaan yang baik dalam mengikuti pembelajaran di sekolah. Namun dari pengamatan langsung di lapangan, penulis juga masih menjumpai ada sebagian kecil anak yang tidak mau mengikuti pembelajaran tertentu di sekolahnya tapi setelah dibujuk oleh salah seorang guru, maka anak tersebut bersedia belajar dan bermain.

Bentuk-bentuk kegiatan belajar dan bermain di sekolah secara keseluruhan sudah dilaksanakan dengan baik dalam hal pelaksanaan holistik integratif. Selain itu, pelaksanaan pengembangannya sudah sesuai dengan yang terdapat dalam kurikulum 2013.

Hasil pelaksanaan pendekatan holistik integratif dapat dilihat dari evaluasi terhadap pembelajaran yang berupa penilaian harian, mingguan, bulanan dan rapor tiap semester. Penilaian pada setiap kegiatan menggunakan enam teknik evaluasi yakni unjuk kerja, observasi, hasil karya, penilaian sikap, portofolio, dan penugasan. Selain penilaian di atas, sekolah juga menggunakan penilaian berupa buku anekdot harian dan buku gejala awal kesulitan anak. Buku-buku ini untuk mengetahui perkembangan kepribadian anak. 
DOI: $\underline{10.31004 / \text { obsesi.v4i1.255 }}$

Evaluasi pendekatan holistik integratif dilakukan melalui pengawasan dan pelaporan secara tertulis realisasi pelasanaan rencana kerja tahunan (RKT). Setiap pertengahan semester, kepala sekolah dan guru melakukan rapat untuk mengetahui kekurangan program-program yang telah dilaksanakan. Melalui kegiatan rapat ini kepala sekolah dan guru-guru dapat berbagi mengenai pembenahan program yang belum terlaksana, kelengkapan administrasi, pengawasan terhadap anak ditingkatkan dan setiap guru diharapkan dapat memberikan masukan untuk pendekatan holistik integratf yang dilaksanakan.

\section{Faktor Pendukung Pelaksanaan PAUD Holistik Integratif di KB TK 'Aisyiyah Ahmad Dahlan Full Day}

Diantara faktor-faktor pendukung dalam pendekatan holistik integratif diantaranya:

Pertama, para guru yang memiliki pengabdian mengajar yang tinggi; motivasi anak untuk aktif mengikuti bermain dan belajar di dalam kelas, luar kelas maupun luar lingkungan PAUD dengan senang.

Status KB TK 'Aisyiyah Nyai Ahmad Dahlan Yogyakarta sebagai sekolah berbasis Islam fullday yang kaya kegiatan belajar dan bermain. Keadaan sarana prasarana dan lingkungan yang menunjang, sudah mencukupi untuk mendukung layanan perlindungan pada anak Manajemen pengelolaan sekolah yang sudah tertata rapi mendukung pelaksanaan PAUD dengan pendekatan holistik integratif.

Pelaksanaan pembelajaran yang sesuai dengan penjabaran kurikulum 2013 dan yayasan yang diacu KB TK 'Aisyiyah Nyai Ahmad Dahlan Full Day Yogyakarta, dengan semboyan mendidik santri penuh dengan kasih sayang ibu.

Semakin meningkatnya kepercayaan dan harapan dari masyarakat dalam pengembangan pembelajaran sehingga meningkatkan kualitas pendidikan. Komunikasi yang lancar antara sekolah (guru), yayasan, warga masyarakat sekitar dan orang tua atau wali santri. Hal ini terbukti dalam wadah komite sekolah yang sering melakukan pertemuan untuk membantu pengembangan sekolah.

Namun demikian terdapat pula hambatan dalam proses pengembangan pendekatan holistic integratif di TK 'Aisyiyah Nyai Ahmad Dahlan Fullday Yogyakarta antara lain katarbelakang guru yang bukan lulusan sarjana pendidikan ank usia dini serta pemberian pola asuh yang beragam pada masing-masing anak

\section{KESIMPULAN}

Pengembangan holistik integratif pada PAUD Full Day di Kota Yogyakarta khususnya di KB TK 'Aisyiyah Ahmad Dahlan Full Day Kotamadya Yogyakarta telah terlaksana dengan baik. Pendekatan holistik integratif yang diterapkan di sekolah kini menjadi acuan keberhasilan pelaksanaan program sehingga menjadi salah satu keunggulan sekolah dalam satuan PAUD.

\section{UCAPAN TERIMA KASIH}

Penulis mengucapkan terima kasih kepada LPPM IAIN Syekh Nurjati Cirebon atas dukungan dana dan fasilitas kegiatan ini. Penelitian ini dibiayai oleh DIPA IAIN Syekh Nurjati Cirebon Kementerian Agama RI tahun 2018. Terimakasih kepada pihak-pihak yang sudah kerjasama menyediakan tempat penelitian yakni keluarga besar KB TK 'Aisyiyah Nyai Ahmad Dahlan (Pendidik, Tenaga Pendidik, Yayasan, Komite/ orang tua).

\section{DAFTAR PUSTAKA}

Alimoeso, S. (2013). Panduan Pelaksanaan Kegiatan BKB yang Terintegrasi Dalam Rangka Penyelenggaraan Pengembangan AUD Holistik Integratif. Jakarta: BKKBN.

Helmawati. (2014). Pendidikan Dalam Keluarga. Bandung: Remaja Rosdakarya. 
KEMENDIKBUD. (2015a). Pedoman Pengelolaan Kelas Pendidikan Anak Usia Dini. Jakarta: Kementrian Pendidikan dan Kebudayaan.

KEMENDIKBUD. (2015b). Pedoman Pengelolaan Pembelajaran Pendidikan Anak Usia Dini. Jakarta: Kementrian Pendidikan dan Kebudayaan.

KEMENDIKBUD. (2015c). Pedoman Pengembangan Tema Pembelajaran Pendidikan Anak Usia Dini. Jakarta: Kementrian Pendidikan dan Kebudayaan.

KEMENDIKBUD. (2015d). Pedoman Penilaian Pembelajaran Pendidikan Anak Usia Dini. Jakarta: Kementrian Pendidikan dan Kebudayaan.

KEMENDIKBUD. (2015e). Petunjuk Teknis Penyelenggaraan PAUD Holistik Integratif di Satuan PAUD [Technical Guide on the Implementation of Holistic Intergative ECD in ECE Units].

Milles, M. B., \& Huberman, A. M. (1992). Analisis Data Kualitatif. Jakarta: UI Press.

Moleong, L. (2005). Metodelogi Penelitian Kualitatif. Bandung: Remaja Rosdakarya.

Alimoeso, S. (2013). Panduan Pelaksanaan Kegiatan BKB yang Terintegrasi Dalam Rangka Penyelenggaraan Pengembangan AUD Holistik Integratif. Jakarta: BKKBN.

Helmawati. (2014). Pendidikan Dalam Keluarga. Bandung: Remaja Rosdakarya.

KEMENDIKBUD. (2015a). Pedoman Pengelolaan Kelas Pendidikan Anak Usia Dini. Jakarta: Kementrian Pendidikan dan Kebudayaan.

KEMENDIKBUD. (2015b). Pedoman Pengelolaan Pembelajaran Pendidikan Anak Usia Dini. Jakarta: Kementrian Pendidikan dan Kebudayaan.

KEMENDIKBUD. (2015c). Pedoman Pengembangan Tema Pembelajaran Pendidikan Anak Usia Dini. Jakarta: Kementrian Pendidikan dan Kebudayaan.

KEMENDIKBUD. (2015d). Pedoman Penilaian Pembelajaran Pendidikan Anak Usia Dini. Jakarta: Kementrian Pendidikan dan Kebudayaan.

KEMENDIKBUD. (2015e). Petunjuk Teknis Penyelenggaraan PAUD Holistik Integratif di Satuan PAUD [Technical Guide on the Implementation of Holistic Intergative ECD in ECE Units].

Milles, M. B., \& Huberman, A. M. (1992). Analisis Data Kualitatif. Jakarta: UI Press.

Moleong, L. (2005). Metodelogi Penelitian Kualitatif. Bandung: Remaja Rosdakarya.

Alimoeso, S. (2013). Panduan Pelaksanaan Kegiatan BKB yang Terintegrasi Dalam Rangka Penyelenggaraan Pengembangan AUD Holistik Integratif. Jakarta: BKKBN.

Helmawati. (2014). Pendidikan Dalam Keluarga. Bandung: Remaja Rosdakarya.

KEMENDIKBUD. (2015a). Pedoman Pengelolaan Kelas Pendidikan Anak Usia Dini. Jakarta: Kementrian Pendidikan dan Kebudayaan.

KEMENDIKBUD. (2015b). Pedoman Pengelolaan Pembelajaran Pendidikan Anak Usia Dini. Jakarta: Kementrian Pendidikan dan Kebudayaan.

KEMENDIKBUD. (2015c). Pedoman Pengembangan Tema Pembelajaran Pendidikan Anak Usia Dini. Jakarta: Kementrian Pendidikan dan Kebudayaan.

KEMENDIKBUD. (2015d). Pedoman Penilaian Pembelajaran Pendidikan Anak Usia Dini. Jakarta: Kementrian Pendidikan dan Kebudayaan.

KEMENDIKBUD. (2015e). Petunjuk Teknis Penyelenggaraan PAUD Holistik Integratif di Satuan PAUD [Technical Guide on the Implementation of Holistic Intergative ECD in ECE Units].

Milles, M. B., \& Huberman, A. M. (1992). Analisis Data Kualitatif. Jakarta: UI Press.

Moleong, L. (2005). Metodelogi Penelitian Kualitatif. Bandung: Remaja Rosdakarya. 